International Journal of Current Advanced Research

ISSN: O: 2319-6475, ISSN: P: 2319 - 6505, Impact Factor: SJIF: 5.995

Available Online at www.journalijcar.org

Volume 6; Issue 4; April 2017; Page No. 3318-3322

DOI: http://dx.doi.org/10.24327/ijcar.2017.3322.0261

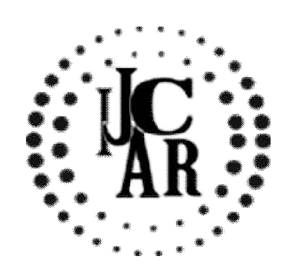

Review Article

\title{
THERAPEUTIC EFFECTS OF CIMICIFUGA RACEMOSA-A SHORT REVIEW
}

\author{
Abijeth.B and Jothi Priya
}

Saveetha Dental College \& Hospitals, 162, P.H.Road, Chennai - 600077

\begin{tabular}{|c|c|}
\hline 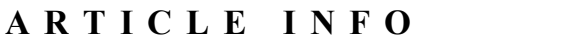 & A B S T R A C T \\
\hline $\begin{array}{l}\text { Article History: } \\
\text { Received } 14^{\text {th }} \text { January, } 2017 \\
\text { Received in revised form } 10^{\text {th }} \text { February, } 2017 \\
\text { Accepted } 22^{\text {nd }} \text { March, } 2017 \\
\text { Published online } 28^{\text {th }} \text { April, } 2017\end{array}$ & $\begin{array}{l}\text { Cimicifuga racemosa is one of the most important of all the indigenous remedies. Its range } \\
\text { of action is quite extensive; it has been quite thoroughly proven; the clinical experience } \\
\text { with it is already large; and it has great possibilities for future development. This plant is } \\
\text { considered to be safe and natural treatment for menopausal complaints such as hot flashes, } \\
\text { profuse sweating and sleep disturbances. }\end{array}$ \\
\hline
\end{tabular}

Key words:

Cimcifuga Racemosa,

Menopausal Treatment

Copyright $@ 2017$ Abijeth.B and Jothi Priya. This is an open access article distributed under the Creative Commons Attribution License, which permits unrestricted use, distribution, and reproduction in any medium, provided the original work is properly cited.

\section{INTRODUCTION}

Cimicifuga racemosa is one of the most important of all the indigenous remedies. Its range of action is quite extensive; it has been quite thoroughly proven; the clinical experience with it is already large; and it has great possibilities for future development.Cimicifuga racemosa commonly going by the name of black cohosh, (latin names: Actaea racemosa and Cimicifuga racemosa) is a perennial plant member ofthebuttercup family, a herb indigenous to North America ${ }^{[1]}$ and Europe, and its rhizomes have long been used for the treatment of a variety of ailments such as diarrhea, sore throat, and rheumatism. Now, black cohosh has become a wellknown alternative herbal medicine with health benefits in treating painful menstrual periods and menopausal disorders. Black cohosh has been revealed to contain triterpene monoglycosides with the cycloartane skeleton, isoflavones, alkaloids, and phenylpropanoids, among which the cycloartane glycosides are its main secondary metabolites and are considered to partially contribute to the pharmacological effects of this herbal medicine ${ }^{[2-8]}$ Menopause, which occurs at ages $45 \sim 55$ years in women, is a physiological process defined by the cessation of menstruation for more than 6 months, caused by ovarian function diminishing naturally or after surgery. The common symptoms such as hot flushes, night sweats, and dyspareunia, dry eyes and dry mouth are seen significantly. ${ }^{[9]}$

*Corresponding author: Abijeth.B

Saveetha Dental College \& Hospitals, 162, P.H.Road,

Chennai - 600077

\section{Therapeutic Effects}

- Anti-climacteric effects: According to study, black cohosh was found to be consistent with a human mu opiate receptor (hMOR) agonist, which may explain its purported beneficial role in alleviating menopausal symptoms. ${ }^{[10]}$

- Anti-coagulation effects: Native black cohosh contains small amounts of salicylic acid.

- Anti-inflammatory activity: The constituent isoferulic acid has also been reported to have anti-inflammatory effects and may decrease muscular spasm.Furthermore, salicylic acid is found in small quantities in black cohosh, and it is presumed that the salicylic acid contributes to the anti-inflammatory and analgesic properties of black cohosh. ${ }^{[11,12]}$

- Antineoplastic effects: Based on a systematic review, there is laboratory evidence of antiproliferative properties of black cohosh but a lack of confirmation from clinical studies for a protective role in cancer prevention. In vitro studies have reported black cohosh to possess inhibitory effects on estrogen responsive cancer cell lines/breast cancer cells. Furthermore, in a cell line study, relatively low concentrations of actein or the methanol/water fraction of black cohosh may cause synergistic inhibition of human breast cancer cell proliferation when combined with different classes of chemotherapy agents. Acetein may activate genes that respond to DNA damage and unfolded protein responses, and enhance apoptosis and repressed cell cycle genes. In an in vitro study conducted on human prostate cancer cells with black cohosh extract, the extract killed hormone-responsive or hormone- 
unresponsive prostate cancer cells by induction of apoptosis and activation of caspases. Another in vivo study demonstrated inhibited PC3 prostate cancer tumor growth with black cohosh and other herbal extracts. The mechanism behind tumor inhibition appeared to be anti-angiogenic by decreasing intratumoral microvessel density. ${ }^{[13-25]}$

- Antioxidant effects: Extracts of black cohosh have protected against induced DNA damage through scavenging of reactive oxygen species. ${ }^{[26-29]}$

- Bone metabolism effects: An isopropanolic extract of black cohosh has been shown to significantly diminish the urinary content of pyridinoline and deoxypyridinoline, specific markers for bone loss, and the morphometric correlates of bone loss associated with ovariectomy. ${ }^{[30-32]}$

- CNS effects: Recent studies suggest that the mechanism of action of black cohosh may be centrally mediated, with possible action at the level of serotonin or dopamine receptors. ${ }^{[33.34]}$

- Endocrine effects: Cimicifugoside contained in black cohosh is believed to affect hypothalamus-pituitary function.

- Estrogenic effects: It is not clear what constituent(s) of black cohosh, if any, possesses estrogenic properties. In animals and in vitro, initial reports of estrogen receptor binding activity stand in contrast with more recent data suggesting no significant estrogen receptor binding activity or estrogenic activities. Two in vitro studies found no effects of black cohosh alone on estrogen receptors, but reported that black cohosh antagonized proliferative effects on cells induced by estradiol.A similar in vitro study on estrogen sensitive breast cancer cells (MCF-7) reported isopropanolic black cohosh extract did not stimulate MCF-7 growth and exerted inhibitory effects on cellular proliferation, indicating strong estrogen-antagonist effects.Several studies have aimed to assess estrogen activity by measuring luteinizing hormone (LH), follicle stimulating hormone (FSH), or prolactin levels.One study reported lower FSH levels (but not LH) in patients treated with black cohosh vs. placebo, although baseline hormone levels were not known in either group.Results from other trials have found no effects on these hormone levels after up to six months of black cohosh therapy. Cimicifuga racemosa ethanolic extract, Ze 450, may inhibit cell proliferation and show antiestrogenic activity. The Cimicifuga racemosa extract bound to the progesterone receptor B1 but did not show progestinlike activity in the T-47D cell line. In an in vitro study using healthy breast tissue of pre- and postmenopausal women, incubation in vitro with black cohosh extract decreased local estrogen formation. ${ }^{[35-57]}$

- Gastrointestinal effects: In an in vitro study, black cohosh extracts moderately but significantly inhibited estrone-3-sulfate (a typical organic anion-transporting polypeptide B (OATP-B) substrate) uptake. As OAT-B is involved in the intestinal absorption of various drugs, black cohosh may decrease the absorption of orally administered substrates of OATP-B. ${ }^{[58]}$

- Neuropharmacologic effects: Black cohosh has been shown to exhibit an action on the central endogenous opioid system in postmenopausal women as evidenced by suppression of mean luteinizing hormone pulse frequency following opioid receptor blockade. ${ }^{[59]}$

- Serum glucose level altering effects: In a randomized trial peri- or post-menopausal women, black cohosh had no demonstrable effects on lipids, glucose, insulin, or fibrinogen. ${ }^{[60]}$

- Serum insulin level altering effects: In a randomized trial peri- or post-menopausal women, black cohosh had no demonstrable effects on lipids, glucose, insulin, or fibrinogen. ${ }^{[60]}$

- Serum lipid level altering effects: In a double-blind randomized, placebo controlled, study in 89 peri- or postmenopausal women experiencing climacteric symptoms, a combination of black cohosh (Cimicifuga racemosa) and St. John's wort (Hypericum perforatum) significantly increased HDL levels. However, in a randomized trial peri- or post-menopausal women, black cohosh had no demonstrable effects on lipids, glucose, insulin, or fibrinogen. ${ }^{[61]}$

- Vascular effects: In a 1962 study, acteina, a constituent of black cohosh, was found to cause peripheral vasodilation, and has been noted to elicit hypotension. ${ }^{[62]}$

- Vasoactive effects: Laboratory study of cimicifugic acids $\mathrm{C}$ and $\mathrm{D}$, and fukinolic acid in the rhizome of black cohosh show vasoactive effects. ${ }^{[63]}$

- Other: In vivo oral administration of black cohosh extract inhibited the anti-IgE-induced passive cutaneous anaphylaxis reaction. ${ }^{7}$ Black cohosh extract also showed inhibitory potential on histamine release. Cimicifugoside from Cimicifuga simplex has been found to inhibit cellular thymidine- ${ }^{3} \mathrm{H}$ uptake, and to act as a selective inhibitor of nucleoside transport into mammalian cells. ${ }^{[64,65]}$

\section{CONCLUSION}

No known contradiction or interaction with other active substances have been demonstrated for Cimicifuga racemosa. Clinical and statistical data ensures that the THERAPEUTIC efficacy of Cimicifuga racemosa for moderate to severe neurovegetative symptoms of climacteric. Good tolerability and low risk of side effects have been confirmed in case reports and clinical studies. Experimental studies indicate that no toxic, mutagenic, carcinogenic, teratogenic effects are seen. This plant is considered to be safe and natural treatment for menopausal complaints such as hot flashes, profuse sweating and sleep disturbances.

\section{References}

1. Foster S. Black cohosh: Cimicifuga racemosa: a literature review. Herbalgram 1999; 45:35-50.

2. Liberman S., J. Womens Health, 7, 525-529 (1998).

3. Stoll W., Therapeutikon, 1, 23 (1984).

4. Radics L., Kajtar-peredy M., Corsano S., Standioli L., Tetrahedron Lett., 1975, 4287-4290.

5. Struck D., Tegtmeier M., Harnischfeger G., Planta Med., 63, 289 (1997).

6. Crum J. D., Cassady J. M., Olmstead P. M., Picha N. J., Proc. West Va. Acad. Sci., 37, 143-147 (1965).

7. Kruse S. O., Lohning A., Pauli G. F., Winterhoff H., Nahrstedt A., Planta Med., 65, 763-764 (1999). 
8. Liske E., Adv. Ther., 15, 45-53 (1998).

9. Evans M, Fleming K, Evans J. Hormone replacement therapy: management of common problems. Mayo Clin Proc. 1995; 70(8): 800-805. pmid:7630222

10. Rhyu, M. R., Lu, J., Webster, D. E., Fabricant, D. S., Farnsworth, N. R., and Wang, Z. J. Black cohosh (Actaea racemosa, Cimicifuga racemosa) behaves as a mixed competitive ligand and partial agonist at the human mu opiate receptor. J Agric Food Chem 12-272006; 54(26):9852-9857. 17177511.

11. Marotta, F., Mao, G. S., Liu, T., Chui, D. H., Lorenzetti, A., Xiao, Y., and Marandola, P. Antiinflammatory and neuroprotective effect of a phytoestrogen compound on rat microglia. Ann $N Y$ Acad Sci 2006; 1089:276-281. 17261775

12. Shibata, M., Ikoma, M., Onoda, M., Sato, F., and Sakurai, N. [Pharmacological studies on the Chinese crude drug "Shoma". III. Central depressant and antispasmodic actions of Cimicifuga rhizoma, Cimicifuga simplex Wormsk (author's transl)]. Yakugaku Zasshi1980; 100(11):1143-1150. 7205558

13. Walji, R., Boon, H., Guns, E., Oneschuk, D., and Younus, J. Black cohosh (Cimicifuga racemosa [L.] Nutt.): safety and efficacy for cancer patients. Support Care Cancer 2007; 15(8):913-921. 17602247

14. Dixon-Shanies, D. and Shaikh, N. Growth inhibition of human breast cancer cells by herbs and phytoestrogens. Oncol Rep 1999;6(6):1383 1387. 10523716

15. Einbond, L. S., Shimizu, M., Xiao, D., Nuntanakorn, P., Lim, J. T., Suzui, M., Seter, C., Pertel, T., Kennelly, E. J., Kronenberg, F., and Weinstein, I. B. Growth inhibitory activity of extracts and purified components of black cohosh on human breast cancer cells. Breast Cancer Res Treat 2004; 83(3):221-231. 14758092

16. Einbond, L. S., Shimizu, M., Ma, H., Wu, H. A., Goldsberry, S., Sicular, S., Panjikaran, M., Genovese, G., and Cruz, E. Actein inhibits the Na+-K+-ATPase and enhances the growth inhibitory effect of digitoxin on human breast cancer cells. Biochem Biophys Res Commun 10-31-2008; 375(4):608-613. 18755149

17. Hostanska, K., Nisslein, T., Freudenstein, J., Reichling, J., and Saller, R. Inhibitory effect of an isopropanolic extract of black cohosh on the invasiveness of MDA$\mathrm{mB} 231$ human breast cancer cells. In Vivo<.em $>$ 2007; 21(2):349-355. 17436587

18. Nesselhut $\mathrm{T}$, Schellhase $\mathrm{C}$, Dietrich $\mathrm{R}$, and et al. [Investigations into the growth-inhibitive efficacy of phytopharmacopia with estrogen-like influences on mammary gland carcinoma cells] (translated from German). Arch Gynecol Obstet 1993; 254:817-818.

19. Struck D, Tegtmeier M, and Harnischfeger G. Flavones in extracts of Cimicifuga racemosa. Planta Med 1997;63:289-290

20. Einbond, L. S., Shimizu, M., Nuntanakorn, P., Seter, C., Cheng, R., Jiang, B., Kronenberg, F., Kennelly, E. J., and Weinstein, I. B. Actein and a fraction of black cohosh potentiate antiproliferative effects of chemotherapy agents on human breast cancer cells. Planta Med2006; 72(13):1200-1206. 16988912

21. Einbond, L. S., Su, T., Wu, H. A., Friedman, R., Wang, X., Ramirez, A., Kronenberg, F., and Weinstein, I. B. The growth inhibitory effect of actein on human breast cancer cells is associated with activation of stress response pathways. Int $J$ Cancer 11-12007;121(9):2073-2083. 17621630

22. Einbond, L. S., Su, T., Wu, H. A., Friedman, R., Wang, X., Jiang, B., Hagan, T., Kennelly, E. J., Kronenberg, F., and Weinstein, I. B. Gene expression analysis of the mechanisms whereby black cohosh inhibits human breast cancer cell growth. Anticancer Res 2007; 27(2):697-712. 17465192

23. Nuntanakorn, P., Jiang, B., Einbond, L. S., Yang, H., Kronenberg, F., Weinstein, I. B., and Kennelly, E. J. Polyphenolic constituents of Actaea racemosa. $J$ Nat Prod 2006; 69(3):314-318. 16562825

24. Hostanska, K., Nisslein, T., Freudenstein, J., Reichling, J., and Saller, R. Apoptosis of human prostate androgen-dependent and -independent carcinoma cells induced by an isopropanolic extract of black cohosh involves degradation of cytokeratin (CK) 18. Anticancer Res2005; 25(1A):139-147. 15816531

25. Ng, S. S. and Figg, W. D. Antitumor activity of herbal supplements in human prostate cancer xenografts implanted in immunodeficient mice. Anticancer Res 2003; 23(5A):3585-3590. 14666653

26. Burdette, J. E., Chen, S. N., Lu, Z. Z., Xu, H., White, B. E., Fabricant, D. S., Liu, J., Fong, H. H., Farnsworth, N. R., Constantinou, A. I., van Breemen, R. B., Pezzuto, J. M., and Bolton, J. L. Black cohosh (Cimicifuga racemosa L.) protects against menadioneinduced DNA damage through scavenging of reactive oxygen species: bioassay-directed isolation and characterization of active principles. $J$ Agric Food Chem 11-20-2002; 50(24):7022-7028. 12428954

27. Jiang, B., Yang, H., Nuntanakorn, P., Balick, M. J., Kronenberg, F., and Kennelly, E. J. The value of plant collections in ethnopharmacology: a case study of an 85-year-old black cohosh (Actaea racemosa L.) sample. $J$ Ethnopharmacol 1-15-2005; 96(3):521528. 15619573

28. Nuntanakorn, P., Jiang, B., Yang, H., CervantesCervantes, M., Kronenberg, F., and Kennelly, E. J. Analysis of polyphenolic compounds and radical scavenging activity of four American Actaea species. Phytochem Anal 2007; 18(3):219228. 17500365

29. Nuntanakorn, P., Jiang, B., Einbond, L. S., Yang, H., Kronenberg, F., Weinstein, I. B., and Kennelly, E. J. Polyphenolic constituents of Actaea racemosa. $J$ Nat Prod 2006; 69(3):314-318. 16562825

30. Nisslein, T. and Freudenstein, J. Effects of an isopropanolic extract of Cimicifuga racemosa on urinary crosslinks and other parameters of bone quality in an ovariectomized rat model of osteoporosis. J Bone Miner Metab 2003; 21(6):370-376. 14586793

31. Seidlova-Wuttke, D., Hesse, O., Jarry, H., Christoffel, V., Spengler, B., Becker, T., and Wuttke, W. Evidence for selective estrogen receptor modulator activity in a black cohosh (Cimicifuga racemosa) extract: comparison with estradiol-17beta. Eur J Endocrinol 2003; 149(4):351-362. 14514351

32. Viereck, V., Grundker, C., Friess, S. C., Frosch, K. H., Raddatz, D., Schoppet, M., Nisslein, T., Emons, G., and Hofbauer, L. C. Isopropanolic extract of black cohosh stimulates osteoprotegerin production by 
human osteoblasts. $J$ Bone Miner Res 2005; 20(11):2036-2043. 16234977

33. Burdette, J. E., Liu, J., Chen, S. N., Fabricant, D. S., Piersen, C. E., Barker, E. L., Pezzuto, J. M., Mesecar, A., van Breemen, R. B., Farnsworth, N. R., and Bolton, J. L. Black cohosh acts as a mixed competitive ligand and partial agonist of the serotonin receptor. $J$ Agric Food Chem 9-10-2003; 51(19):5661-5670. 12952416

34. Jarry, H., Metten, M., Spengler, B., Christoffel, V., and Wuttke, W. In vitro effects of the Cimicifuga racemosa extract BNO 1055. Maturitas 3-14-2003; 44 Suppl 1:S31-S38. 12609557

35. Jarry, H., Harnischfeger, G., and Duker, E. [The endocrine effects of constituents of Cimicifuga racemosa. 2. In vitro binding of constituents to estrogen receptors]. Planta Med 1985; 51(4):316319. 4070446

36. Liu, Z., Yang, Z., Zhu, M., and Huo, J. [Estrogenicity of black cohosh (Cimicifuga racemosa) and its effect on estrogen receptor level in human breast cancer MCF-7 cells]. Wei Sheng Yan Jiu 2001; 30(2):7780. 11321955

37. Beck, V., Unterrieder, E., Krenn, L., Kubelka, W., and Jungbauer, A. Comparison of hormonal activity (estrogen, androgen and progestin) of standardized plant extracts for large scale use in hormone replacement therapy. J Steroid Biochem Mol Biol 2003; 84(2-3):259-268. 12711012

38. Borrelli, F., Izzo, A. A., and Ernst, E. Pharmacological effects of Cimicifuga racemosa. Life Sci 7-25-2003; 73(10):1215-1229. 12850238

39. Lupu, R., Mehmi, I., Atlas, E., Tsai, M. S., Pisha, E., Oketch-Rabah, H. A., Nuntanakorn, P., Kennelly, E. J., and Kronenberg, F. Black cohosh, a menopausal remedy, does not have estrogenic activity and does not promote breast cancer cell growth. Int J Oncol 2003; 23(5):1407-1412. 14532983

40. Liu, J., Burdette, J. E., Xu, H., Gu, C., van Breemen, R. B., Bhat, K. P., Booth, N., Constantinou, A. I., Pezzuto, J. M., Fong, H. H., Farnsworth, N. R., and Bolton, J. L. Evaluation of estrogenic activity of plant extracts for the potential treatment of menopausal symptoms. $J$ Agric Food Chem 2001; 49(5):2472-2479. 11368622

41. Liu, Z., Yang, Z., Zhu, M., and Huo, J. [Estrogenicity of black cohosh (Cimicifuga racemosa) and its effect on estrogen receptor level in human breast cancer MCF-7 cells]. Wei Sheng Yan Jiu 2001;30(2):7780. 11321955

42. Einer-Jensen, N., Zhao, J., Andersen, K. P., and Kristoffersen, K. Cimicifuga and Melbrosia lack oestrogenic effects in mice and rats. Maturitas 1996 ; 25(2):149-153. 8905606

43. Mahady, G. B. Is black cohosh estrogenic? Nutr.Rev 2003; 61(5 Pt 1):183-186. 12822708

44. Nisslein, T. and Freudenstein, J. Concomitant administration of an isopropanolic extract of black cohosh and tamoxifen in the in vivo tumor model of implanted RUCA-I rat endometrial adenocarcinoma cells. Toxicol

Lett 5-2-2004;

150(3):271275. 15110078

45. Oerter, Klein K., Janfaza, M., Wong, J. A., and Chang, R. J. Estrogen bioactivity in fo-ti and other herbs used for their estrogen-like effects as determined by a recombinant cell bioassay. $J$ Clin Metab 2003; 88(9):4077-4079. 12970265

46. Onorato, J. and Henion, J. D. Evaluation of triterpene glycoside estrogenic activity using LC/MS and immunoaffinity extraction. Anal Chem 10-1-2001; 73(19):4704-4710. 11605850

47. Zava, D. T., Dollbaum, C. M., and Blen, M. Estrogen and progestin bioactivity of foods, herbs, and spices. Proc Soc Exp Biol Med1998; 217(3):369378. 9492350

48. Zhang, L., Khan, I. A., Willett, K. L., and Foran, C. M. In vivo effects of black cohosh and genistein on estrogenic activity and lipid peroxidation in Japanese Medaka (Oryzias latipes). J Herb Pharmacother 2003; 3(3):33-50. 15277055

49. Duker, E. M., Kopanski, L., Jarry, H., and Wuttke, W. Effects of extracts from Cimicifuga racemosa on gonadotropin release in menopausal women and ovariectomized rats. Planta Med 1991; 57(5):420424. 1798794

50. Zierau, O., Bodinet, C., Kolba, S., Wulf, M., and Vollmer, G. Antiestrogenic activities of Cimicifuga racemosa extracts. J Steroid Biochem Mol Biol 2002; 80(1):125-130. 11867271

51. Jarry, H. and Harnischfeger, G. [Endocrine effects of constituents of Cimicifuga racemosa. 1. The effect on serum levels of pituitary hormones in ovariectomized rats]. Planta Med 1985; 51(1):46-49. 3925475

52. Liske E, Wüstenberg $P$, and Boblitz N. Humanpharmacological investigations during treatment of climacteric complaints with Cimicifuga racemosa (Remifemin): No estrogen-like effects. ESCOP 2001; $1: 1$.

53. Siess VM and Seybold G. [Studies on the effects of Pulsatilla pratensis, Cimicifuga racemosa and Aristolochia clematitis on the estrus in infantile and castrated white mice]. Arzneimittelforschung 1960;10:514-520

54. Bodinet, C. and Freudenstein, J. Influence of marketed herbal menopause preparations on MCF-7 cell proliferation. Menopause2004; 11(3):281289. 15167307

55. Lehmann-Willenbrock, E. and Riedel, H. H. [Clinical and endocrinologic studies of the treatment of ovarian insufficiency manifestations following hysterectomy with intact adnexa]. Zentralbl Gynakol 1988; 110(10):611-618. 2841818

56. Jacobson, J. S., Troxel, A. B., Evans, J., Klaus, L., Vahdat, L., Kinne, D., Lo, K. M., Moore, A., Rosenman, P. J., Kaufman, E. L., Neugut, A. I., and Grann, V. R. Randomized trial of black cohosh for the treatment of hot flashes among women with a history of breast cancer. J Clin Oncol5-15-2001;19(10):27392745. 11352967

57. Liske E and Wüstenberg P. Therapy of climacteric complaints with Cimicifuga racemosa: herbal medicine with clinically proven evidence [poster presentation]. Menopause 1998;5(4):250.

58. uchikami, H., Satoh, H., Tsujimoto, M., Ohdo, S., Ohtani, H., and Sawada, Y. Effects of herbal extracts on the function of human organic anion-transporting polypeptide OATP-B. Drug Dispos 2006;34(4):577-582. 16415120 
59. Reame, N. E., Lukacs, J. L., Padmanabhan, V., Eyvazzadeh, A. D., Smith, Y. R., and Zubieta, J. K. Black cohosh has central opioid activity in postmenopausal women: evidence from naloxone blockade and positron emission tomography neuroimaging. Menopause 2008; 15(5):832-840. 18521048

60. Spangler, L., Newton, K. M., Grothaus, L. C., Reed, S. D., Ehrlich, K., and LaCroix, A. Z. The effects of black cohosh therapies on lipids, fibrinogen, glucose and insulin. Maturitas 6-20-2007;57(2):195-204. 17275226

61. Chung, D. J., Kim, H. Y., Park, K. H., Jeong, K. A., Lee, S. K., Lee, Y. I., Hur, S. E., Cho, M. S., Lee, B. S., Bai, S. W., Kim, C. M., Cho, S. H., Hwang, J. Y., and Park, J. H. Black cohosh and St. John's wort (GYNO-Plus) for climacteric symptoms. Yonsei Med J 4-30-2007; 48(2):289-294. 17461529
62. Genazzani E and Sorrentino L. Vascular action of acteina: active constituent of Actaea racemosa L. Nature 1962; 194(4828):544-545.

63. Noguchi, M., Nagai, M., Koeda, M., Nakayama, S., Sakurai, N., Takahira, M., and Kusano, G. Vasoactive effects of cimicifugic acids $\mathrm{C}$ and $\mathrm{D}$, and fukinolic acid in cimicifuga rhizome. Biol Pharm Bull 1998; 21 (11): 1163-1168. 9853406

64. Hemmi, H., Kusano, G., and Ishida, N. Selective inhibition of nucleoside transport into mouse lymphoma L- 5178 Y cells by cimicfugoside. $J$ Pharmacobiodyn 1980; 3(12):636-642. 7277178

65. Hemmi H, Kitame F, Ishida N, and et al. Inhibition of thymidine transport into phytohemagglutininstimulated lymphocytes by triterpenoids from Cimicifuga species. J Pharm Dyn 1979; 2:339349.

\section{How to cite this article:}

Abijeth.B and Jothi Priya (2017) ' Therapeutic Effects Of Cimicifuga Racemosa-A Short Review', International Journal of Current Advanced Research, 06(04), pp. 3318-3322.

DOI: http://dx.doi.org/10.24327/ijcar.2017.3322.0261 